УДК [378.091.212]:373.2.013-051

DOI:

Валентина Ляпунова, доктор педагогічних наук, професор кафедри дошкільної освіти і сочіальної роботи

Мелітопольського державного педагогічного університету імені Богдана Хмельницького

Світлана Жейнова, кандидат педагогічних наук,

старший викладач кафедри дошкільної освіти і соиіальної роботи

Мелітопольського державного педагогічного університету імені Богдана Хмельницького

\title{
ВИКОРИСТАННЯ МЕТОДІВ ФОРМУВАННЯ ТВОРЧИХ ЯКОСТЕЙ МАЙБУТНІХ ВИХОВАТЕЛІВ У ПРОЦЕСІ ПРОФЕСІЙНОЇ ПІДГОТОВКИ
}

У статті порушено актуальну проблему сьогодення. Актуальність перебуває у площуині інноваційних напрямів розвитку національної системи вищої освіти й передбачає зміни в професійних установках, ціннісному світогляді майбутніх вихователів закладів дошкільної освіти, створенні сприятливих умов для реалізації програми педагогічного саморозвитку та самовдосконалення майстра педагогічної дії. Сучасний освітній прочес закладу дошкільної освіти вимагає від педагога інтелекту, усвідомленого прийняття рішень, гнучкого реагування тощуо. Важливим в означеному контексті є розвиток творчого мислення та наявність творчих якостей у вихователя дітей дошкільного віку. Цінним є визначення й впровадження методів формування творчих якостей майбутніх вихователів закладів дошкільної освіти у процес професійної підготовки.

Ключові слова: творчі якості; формування творчих якостей; вихователь закладу дошкільної освіти; професійна підготовка у закладі вищої освіти; методи формування творчих якостей.

Jim. 9.

Valentyna Lyapunova, Doctor of Sciences (Pedagogy), Professor of the Preschool Education and Social Work Department Melitopol Bohdan Khmelnytskiy State Pedagogical University Svitlana Zheinova, Ph.D.(Pedagogy), Senior Lecturer of Preschool Education and Social Work Department Melitopol Bohdan Khmelnytskiy State Pedagogical University

\section{USE OF METHODS OF FORMATION OF CREATIVE QUALITIES OF FUTURE PRESCHOOL TEACHERS IN PROCESS OF PROFESSIONAL TRAINING}

The article raises the topical issue of today. The relevance is in the plane of innovative directions of development of the national system of higher education and involves changes in professional attitudes, values of future educators of preschool institutions, creating favorable conditions for the implementation of the program of pedagogical selfdevelopment and self-improvement of the master of pedagogical action. This determines the requirement to train such educators of preschool children who are able to perform their duties at a high professional level, find a nonstandard and most effective way to solve educational problems, to form a creative personality of a preschool child. This is the significance of the problem of forming the creative qualities of future educators of preschool education institutions in the process of professional training.

The modern educational process of a preschool institution requires from the teacher intelligence, conscious decision-making, flexible response, etc. Important thing in this context is the development of creative thinking and the presence of creative qualities in the educator of preschool children. It is valuable to define and implement methods of forming the creative qualities of future educators of preschool institutions in the process of professional training.

One of the main tasks of professional training of teachers is the formation of creative qualities, equipping future professionals with the ability to find non-standard and most effective ways to solve educational problems, to form a creative personality of the child. Characterizing the state of study of this problem, we can state the fact that recently increased interest in the formation of the personality of the teacher of preschool education. The practical significance of the problem of professional training of future educators of preschool education institutions has led to a wide study of its applied aspects.

Keywords: creative qualities; formation of creative qualities; teacher of the institution of preschool education; vocational training; methods of formation of creative qualities.

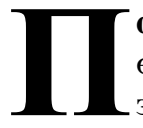

остановка проблеми. Уведення європейських стандартів передбачає зміщення акцентів у побудові

(c) В. Ляпунова, С. Жейнова, 2021 педагогічних процесів у бік суб'єкт-суб'єктної, ініціативної, демократичної, водночас відповідальної версії організації навчання, пошуку 


\section{ВИКОРИСТАННЯ МЕТОДІВ ФОРМУВАННЯ ТВОРЧИХ ЯКОСТЕЙ МАЙБУТНІХ ВИХОВАТЕЛІВ У ПРОЦЕСІПРОФЕСІЙНОӤ ПДГОТОВКИ}

способів інтенсивного вивільнення творчого потенціалу студентів і викладачів і відтворено у діяльності такого незалежного суспільного органу, як Національне агентство із забезпечення якості вищої освіти. Незважаючи на велику кількість праць, присвячених проблемі творчості взагалі та формуванню творчих якостей фахівців різних професій зокрема, проблема формування творчих якостей майбутніх вихователів закладів дошкільної освіти у процесі професійної підготовки залишається актуальною.

Аналіз основних досліджень і публікацій. Особлива увага приділялась дослідженню творчості педагога як фахівця, який за метою і змістом власної професійної діяльності створює умови для розвитку творчих здібностей своїх вихованців (В. Вітюк, І. Гриненко, Н. Єсіна, П. Каптерєв, Я. Коменський, Л. Корольова, В. Корольський, Л. Кравченко, Т. Крамаренко, Т. Левченко, О. Локтюшина, А. Машталір, О. Медведєва, Ю. Мох, Й. Песталоцці, В. Риндак Ж.-Ж. Руссо, Н. Сегеда, С. Семеріков, С. Сисоєва, С. Шандрук, С. Шокалюк, В. Шубинський, В. Ягупов, Т. Яковенко та ін.).

Окремі аспекти проблеми формування творчих якостей майбутніх вихователів закладів дошкільної освіти у процесі професійної підготовки знайшли відображення у наукових дослідженнях М. Бадіци, С. Гаврилюк, О. Донченко, О. Ємчик, О. Листопада, В. Любивої, А. Федорович та ін.

Формування мети статті. Мета викладу матеріалу полягає у дослідженні наукових поглядів щодо проблеми пошуку методів формування творчих якостей майбутніх вихователів.

Виклад основного матеріалу дослідження 3 повним обгрунтування отриманих наукових результатів. У педагогіці вищої школи під методами навчання розуміють впорядковані способи взаємопов'язаної, цілеспрямованої діяльності педагога й студентів, спрямовані на ефективне розв'язання освітніх завдань, що реалізуються через систему прийомів і засобів навчальної діяльності.

У стандарті вищої освіти України першого (бакалаврського) рівня спеціальності 012 Дошкільна освіта надано перелік методів професійної підготовки майбутніх вихователів закладів дошкільної освіти: словесні, наочні, практичні, практико-теоретичні, пояснювальноілюстративні, репродуктивні, частково-пошукові проблемні, дослідницькі, індуктивні, дедуктивні [6].

Необхідним уважаємо наголосити на домінуючій ролі продуктивних методів навчання у підготовці майбутнього вихователя дітей дошкільного віку, що надасть можливість студентам спробувати власні сили у процесі розв'язання змодельованих проблемних завдань, тобто через аналіз проблемних ситуацій, розв'язання творчих завдань, які дають змогу побачити незвичайне у звичайному, викликають зацікавленість у вивченні матеріалу.

Так, Д. Чернілевський та М. Томчук пропонують розглядати методи навчання у закладі вищої освіти за розв'язанням дидактичного завдання (методи пояснення, відпрацювання і контролю) та за характером пізнавальної діяльності (репродуктивні і продуктивні). До репродуктивних вчені відносять методи повідомлення “готового” знання шляхом інформативного викладу, проблемного викладу змісту матеріалу і дедуктивного виведення, до продуктивних - метод пояснення шляхом організації евристичного пошуку, що частково скеровується викладачем. Метод пояснення шляхом організації отримання знання в самостійному евристичному пошуку полягає у тому, що викладач не повідомляє потрібні знання про об'єкти і дії з ними, а дає студентові завдання на їх самостійне знаходження. При цьому здобувач здійснює пошук не повністю самостійно, a при непрямому спрямуванні пошуку викладачем, який ставить навідні питання, дає підказки та ін. Студент аналізує умови завдання, висуває гіпотези про шляхи його виконання i одержує інформацію про правильність своїх ідей від викладача або за допомогою перевірки [7, 310 312].

Детально розглядає класифікацію методів навчання за характером (ступенем самостійності й творчості) діяльності тих, кого навчають у закладі вищої освіти В. Ортинський, а саме: пояснювально-ілюстративний, репродуктивний, проблемного викладення, частково-пошуковий (евристичний), дослідницький [4, 190-191]. Оскільки успіх навчання загалом залежить від внутрішньої активності тих, кого навчають, то ступінь самостійності та творчості, на нашу думку, має бути важливим критерієм у виборі методів для формування творчих якостей.

Під час використання пояснювальноілюстративного методу студенти здобувають знання, слухаючи розповідь, лекцію, з навчальної або методичної літератури, через екранний посібник у “готовому” вигляді. Сприймаючи й осмислюючи факти, оцінки, висновки, вони залишаються у межах репродуктивного (відтворювального) мислення. Такий метод якнайширше застосовують для передавання значного масиву інформації. Його можна 


\section{ВИКОРИСТАННЯ МЕТОДІВ ФОРМУВАННЯ ТВОРЧИХ ЯКОСТЕЙ МАЙБУТНІХ ВИХОВАТЕЛІВ У ПРОЦЕСІПРОФЕСІЙНОӤ ПДГОТОВКИ}

використовувати для викладення й засвоєння фактів, підходів, оцінок, висновків. Альтернативою пояснювально-ілюстративного методу вважаємо один з інтерактивних методів навчання - лекціювізуалізацію.

Особливе значеня у навчанні студентів закладу вищої освіти має застосування репродуктивного методу, тобто вивчення на основі зразка або правила. Діяльність тих, кого навчають, є алгоритмічною, тобто відповідає інструкціям, розпорядженням, правилам - в аналогічних до представленого зразка ситуаціях.

Під час використання методу проблемного викладення, застосовуючи будь-які джерела й засоби, педагог, перш ніж викладати матеріал, ставить проблему, формулює пізнавальне завдання, а потім, розкриваючи систему доведень, порівнюючи погляди, різні підходи, демонструє спосіб розв'язання поставленого завдання. Студенти стають ніби свідками і співучасниками наукового пошуку [4].

Суть частково-пошукового або евристичного методу полягає в організації активного пошуку розв'язання висунутих педагогом чи самостійно сформульованих студентом пізнавальних завдань. Виконання таких завдань може відбуватися під керівництвом педагога на основі евристичних програм і вказівок. Процес мислення у такому разі набуває продуктивного характеру, але його поетапно скеровує й контролює викладач або самі студенти на основі роботи з навчальними посібниками та програмами, зокрема й комп'ютерними.

Особливе місце серед методів навчання належить дослідницькому методу. Після аналізу матеріалу, постановки проблем і завдань та короткого усного або письмового інструктажу ті, кого навчають, самостійно вивчають літературу, джерела, ведуть спостереження й виміри та виконують інші пошукові дії. Ініціатива, самостійність, творчий пошук виявляються у дослідницькій діяльності найповніше. Методи навчальної роботи безпосередньо переходять у методи, які імітують, а іноді й реалізують науковий пошук [4, 190-191]. На нашу думку, дослідницька діяльність студентів у творчому пошуку має важливе значення у процесі засвоєння i відтворення інформації студентами під час професійної підготовки в закладах вищої освіти.

Особливе значення у формуванні творчих якостей майбутніх вихователів закладів дошкільної освіти, на нашу думку, має застосування саме евристичного та дослідницького методів. Наголосимо, що їх застосування доповнює і завершує функції синтезу та інтегрує увесь процес підготовки фахівців в галузі дошкільної освіти. Актуалізація цієї проблеми посилюється тим, що в сучасних умовах обсяг наукової інформативності стрімко зростає. Дедалі важливішою проблемою вищої освіти стає самостійна орієнтація здобувачів у потоці наукової інформації та уміння поповнювати свої знання, самостійно знаходити шляхи поповнення знань для розв'язання питань у майбутній професійній діяльності.

З метою оптимізації аудиторної і позааудиторної суб’єкт-суб’ єктної навчальної взаємодії майбутніх педагогів через створення розвивального середовища креативного характеру Л. Корольовою було запроваджено практико-орієнтовані креативно-іноваційні форми й методи викладаня в ЗВО, а саме: творчі дискусії, синквейни, діаманти, диспути, мікродослідженя, колоквіуми, творчі проєкти, проблемно-моделювальні заняття, система тренінгів, метод “семикратного пошуку”, складаня “дерева рішень”, “стрічки часу” за допомогою відповідних web-pесурсів, хмарного сервісу Google [2, 11].

Розв'язання педагогічних задач О. Смчик уважає своєрідним підготовчим етапом, тренуванням у розв'язанні завдань, наявних у реальному педагогічному процесі, оскільки використання педагогічних ситуацій допомагає студентові відчути себе суб'єктом освітнього процесу, прогнозувати свої дій у суперечливих ситуаціях або передбачати чи усувати негативні наслідки $[1,154]$.

На думку В. Корольського, Т. Крамаренка, C. Семерікова, С. Шокалюка, формування творчих якостей відбувається саме в процесі розв'язання навчально-творчих задач. Задачі мають не стільки сприяти закріпленню знань, тренуванню у їх застосуванні, скільки формувати дослідницький стиль розумової діяльності, метод підходу до виучуваних явищ $[3,45]$. Розвиває творчі якості також пошук нестандартного методу для розв'язування пізнавальної задачі $[3,187]$.

На підставі урахування думки дослідників, враховуючи типології навчально-творчих задач, можна виокремити типи творчих завдань, запитань, творчих вправ, що доцільно використовувати для формування творчих якостей майбутніх вихователів у процесі професійної підготовки, наприклад, під час аудиторної роботи, у позанавчальному процесі, під час виробничих практик. Ми вважаємо за потрібне до процесу формування творчих якостей майбутніх вихователів запровадити низку творчих завдань, запитань, вправ тощо. Це сприятиме формуванню творчих якостей майбутніх вихователів відповідно 


\section{ВИКОРИСТАННЯ МЕТОДІВ ФОРМУВАННЯ ТВОРЧИХ ЯКОСТЕЙ МАЙБУТНІХ ВИХОВАТЕЛІВ У ПРОЦЕСІ ПРОФЕСІЙНОӤ ПДГОТОВКИ}

до компонентів, що зазначені у розробленій нами структурі.

3 огляду на численні класифікації методів навчання, схарактеризованих у теорії педагогіки вищої освіти (за джерелом знань, за характером пізнавальної діяльності тощо), у виборі методів формування творчих якостей майбутніх вихователів закладів дошкільної освіти ми орієнтувалися на активну позицію студента як суб' єкта освітнього процесу - чи перебуває він у позиції виконавця, слухача, чи в різних видах міжособистісної взаємодії має можливість виявити свою суб'єктність як носія творчих якостей, свою особистісну активність, відкрити нове.

Так, під час формування творчих якостей майбутніх вихователів закладів дошкільної освіти пропонуємо використовувати методи актуалізачіі обізнаності в питаннях самопізнання творчих якостей, що надасть можливість осягнути знання щодо усвідомлення студентом власних творчих якостей та вмотивує на продуктивну творчу діяльність та метод актуалізації творчих вправ, що розглядається нами як спосіб підвищення пізнавальної активності, а також потреби студента в самоактуалізації, розкритті і розширенні своїх творчих можливостей.

Зауважимо, що можливість ставити перед собою нові цілі та завдання, спрямовані на вихід за межі заданого, на пошук і відкриття нових закономірностей і способів розв'язання педагогічних ситуацій у майбутній професії вихователя закладу дошкільної освіти надасть можливість студентам у процесі професійної підготовки використання таких методів, що передбачають активну творчу діяльність.

На доцільності використання у професійній підготовці майбутніх педагогів навчальнопрофесійних задач, що виступають аналогом реальних педагогічних та дидактичних задач, наголошують багато вчених. На нашу думку, розв'язування педагогічних задач сприятиме формуванню прагнення майбутніх вихователів до засвоєння нового професійного досвіду, розвитку критичного мислення, пізнавальної активності.

Одним із ефективних у педагогічному процесі вищої школи методів формування творчих якостей вихователя закладу дошкільної освіти вважаємо використання методу розв'язування педагогічної задачі. Проблема у стадії розв'язання створює проблемну ситуацію, яка змушує майбутнього вихователя актуалізувати свої творчі потенції: фантазувати, будувати гіпотези, висувати нові ідеї, здійснювати уявні експерименти, переосмислювати відомі способи, методи, залучати критичне мислення від зародження проблемної ситуації, виникнення пізнавальної мотивації до знаходження способів розв'язання навчально-педагогічної проблеми й доведення правильності знайденого розв'язку. Утворені контексти майбутньої професійно-педагогічної діяльності необхідно врахувати в проблемному навчанні, де буде змодельовано не умови передачі та прийому готової інформації, а ситуації з уявної професійної діяльності, які вимагають залучення творчих якостей студента. Такі ситуації, в яких майбутній вихователь закладу дошкільної освіти відчуває відсутність готового стандарту (алгоритму, правила, способу) їх розв'язання і намагається їх знайти, розуміємо проблемними ситуаціями.

Отже, в закладі вищої освіти під час професійної підготовки майбутній вихователь повинен бути поставлений в умови, наближені до його практичної діяльності за допомогою активних методів та засобів навчання, що готують до спілкування з дітьми дошкільного віку.

Для ефективного особистісного і професійного розвитку майбутніх педагогів О. Отич пропонує використовувати і педагогіку мистецтва, й педагогіку професійної мистецької освіти (особливо театральну педагогіку) в їхньому взаємозв'язку, оскільки діяльність педагога як творча суб'єкт-суб' єктна взаємодія є найбільш спорідненою 3 діяльністю театральних діячів, передусім актора й режисера. Тому використання педагогічних можливостей театру і театральних методів у професійній підготовці майбутніх педагогів $є$ одним із найбільш ефективних шляхів формування творчої особистості та розвитку неповторної, яскравої індивідуальності, артистичності вихователя [5, 18].

Погоджуючись 3 такою думкою, вбачаємо необхідність використання методу перевтілення, що дозволить здобувачеві вищої освіти у творчій взаємодії виявити творчі якості. Саме в театральній діяльності творчі якості майбутнього вихователя матимуть повний і яскравий вияв у довільному відтворенні певного сценарію, характерів героїв. Завдання такої спрямованості можна використати під час організації виробничих практик у закладах дошкільної освіти, що нададуть майбутнім вихователям можливість занурення під час виконання ролі застосування діалогу як двостороннього обміну інформацією та полілогу як обміну думками під час організації заходу, де кожен учасник матиме власну точку зору.

Ефект кооперативної творчості виділяють у своєму дослідженні М. Гарайгордобиль та Л. Берруеко, що найкраще реалізується під час 


\section{ВИКОРИСТАННЯ МЕТОДІВ ФОРМУВАННЯ ТВОРЧИХ ЯКОСТЕЙ МАЙБУТНІХ ВИХОВАТЕЛІВ У ПРОЦЕСІПРОФЕСІЙНОӤПІДГОТОВКИ}

ігрової програми, яка спрямована на розвиток творчого мислення [9, 610]. Нам імпонує думка вчених про те, що саме кооперативна творчість, у порівнянні з діяльністю змагального характеру, є більш продуктивною та результативною для розвитку творчої особистості.

Рушійною силою розвитку особистості студентів і викладачів $є$ їхня спільна творча діяльність і спілкування, у процесі яких ідеї стають інструментом, особистим надбанням студентів, задають загальну спрямованість самореалізації, саморозвитку та професійному самовдосконаленню у творчій діяльності.

Методи навчання за навчально-пізнавальним характером у сенсі активізації навчання, зростанням його навчально-пізнавального характеру П. Шевчук і П. Фенріх класифікують на неімітаційні (лекція-бесіда, лекція-диспут, проблемна лекція, лекція з розгляду конкретних ситуацій, лекція-вікторина, лекція-консультація, лекція-прескоференція, теоретична співбесіда, метод залучення, метод мозкового штурму) та імітаційні (ігрові, неігрові) [8, 10]. Більш ефективними для роботи зі студентами науковці вважають інтерактивні методи навчання, які, в основному, мають імітаційні форми проведення. Розглянемо докладніше можливості використання цих методів у процесі професійної підготовки майбутніх вихователів.

Особливістю інтерактивних методів навчання $\epsilon$ продуктивний, творчий, пошуковий характер та стимулювання пізнавальної діяльності студентів. Вони грунтуються на діалогах, що передбачають вільний обмін думками щодо шляхів подолання певної проблеми. Інтерактивні методи, як зазначає П. Фенріх, не можуть бути “мистецтвом заради мистецтва”, вони повинні чітко реалізувати конкретну мету, спрямовувати діяльність на досягнення очікуваних результатів. Сама суть інтерактивності вводить елемент непередбачуваності. Таким чином, результат $є, 3$ одного боку, ефектом підготовки викладача, а 3 іншого - наслідком різноманітних реакцій студентів, що виникають під час застосування, створенням нової творчої освітньої якості [8, 63]. Методом активізації творчої діяльності може виступати дискусія, запитання у ході лекції. Необхідність формулювання висловлювань студентів вимагає розуміння змісту. Проте активність в інтерактивному навчанні повинна йти глибше. В них має знайти місце мистецтво аргументації, пошуку істини, самостійного розв'язання проблеми, подолання труднощів у розумінні, прагнення до перманентної самоосвіти. Bci інтерактивні методи в кінцевому рахунку повинні, власне, служити прагненню до самостійного розв'язання проблеми, засвоєння знань, тренування вмінь і формування власної позиції $[8,63]$.

Для формування творчих якостей майбутніх вихователів закладів дошкільної освіти особливого значення набуває використання у процесі професійної підготовки саме інтерактивних методів, що є дієвими і навчають активності, заохочують до неї. Найголовнішою особливістю використання інтерактивних методів у процесі формування творчих якостей майбутнього вихователя $є$ позиція студента як активного учасника освітнього процесу.

Сучасні інтерактивні методи мають право на існування під певними оригінальними назвами, як наприклад, запропоновано П. Шевчуком і П. Фенріхом: “Снігова куля", “Килимок ідей”, “Капелюхи”, “Анкета 5 з 25”, “Оксфордські дебати”, “Метод генерування ідей 6-3-5” [8, 63].

Висновки 3 даного дослідження i перспективи подальших розвідок у даному напрямку. Для залучення студентів до творчої діяльності та взаємодії у відповідності до їх потреб та індивідуальних особливостей розвитку творчих якостей у процесі професійної підготовки необхідно використовувати інтерактивні методи. У процесі інтерактивного навчання (діалогового, взаємодіючого) здобувачі мають можливість обмінюватися думками, ідеями, пропозиціями, а викладач стає організатором спільної діяльності, ділової співпраці, творчого пошуку, створює атмосферу щирості, поваги. Під час інтерактивного навчання освітній процес організовується у такий спосіб, що практично всі студенти виявляються залученими до процесу пізнання, мають можливість рефлексувати 3 приводу того, що вони знають і думають. У такому контексті вважаємо за необхідне надавати пріоритет саме евристичним, дослідницьким та інтерактивним методам, що і забезпечить формування творчих якостей майбутніх вихователів закладів дошкільної освіти.

Перспективи подальших досліджень убачаємо в розробці інноваційних технологій вдосконалення творчих якостей вихователя закладу дошкільної освіти впродовж життя.

\section{ЛІТЕРАТУРА}

1. Ємчик О. Г. Розвиток творчого потенціалу магістрів дошкільної освіти у процесі професійної підготовки: дис. ... канд. пед. наук: 13.00.04 / 2018. Луцьк. 318 с.

2. Корольова Л. М. Підготовка майбутніх учителів до розвитку креативних здібностей учнів у навчально-виховній діяльності початкової школи: 


\section{ВИКОРИСТАННЯ МЕТОДІВ ФОРМУВАННЯ ТВОРЧИХ ЯКОСТЕЙ МАЙБУТНІХ ВИХОВАТЕЛІВ У ПРОЦЕСІПРОФЕСІЙНОӤПІГОТОВКИ}

автореф. дис. ... канд. пед. наук: 13.00.04 / 2019. Запоріжжя. 23 с.

3. Корольський В. В., Крамаренко Т. Г., Семеріков С. О., Шокалюк С. В. Інноваційні інформаційно-комунікаційні технології навчання математики. Книжкове видавництво Кирєєвського, $2009.324 \mathrm{c}$.

4. Ортинський В. Л. Педагогіка вищої школи: навч. посіб. Центр учбової літератури. 2019. 472 с.

5. Отич О. Педагогіка мистецтва: від історичної практики - до теоретичного осмислення. Рідна школа. №6. 2010. С. 14-19.

6. Стандарт вищої освіти України: перший (бакалаврський) рівень, галузь знань 01 - “Освіта/ Педагогіка", спеціальність 012 - “Дошкільна освіта". Отримано 3: https://mon.gov.ua/storage/ app/media/vishcha-osvita/zatverdzeni\%20standarty/ 2019/11/22/2019-11-22-012doshkilna-B.pdf.

7. Чернілевський Д. В., Томчук М. І. Педагогіка та психологія вищої школи. Вінн. соц.-екон. ін.-тут Ун-ту “Україна". 2006. 402 с.

8. Шевчук П., Фенріх П. Інтерактивні методи навчання: навч. посібник. Щецін: Вид-во WSAP, 2005. $170 \mathrm{c}$.

9. Effects of a play program on creative thinking of preschool children M Garaigordobil, L. Berrueco. The Spanish Journal of Psychology Copyright 2011 by The Spanish Journal of Psychology, 2011. Vol. 14, No. 2. 608-618.

\section{REFERENCES}

1. Yemchyk, O. (2018). Rozvytok tvorchoho potentsialu mahistriv doshkilnoi osvity u protsesi profesiinoi pidhotovky [Development of creative potential of masters of preschool education in the process of professional training]. Candidate's thesis. Lutsk, 318 p. [in Ukrainian].

2. Korolyova, L. (2019). Pidhotovka maibutnikh uchyteliv do rozvytku kreatyvnykh zdibnostei uchniv u navchalno-vykhovnii diialnosti pochatkovoi shkoly [Preparation of future teachers for the development of creative abilities of students in the educational activities of primary school]. Extended abstract of candidate's thesis. Zaporozhye, 23 p. [in Ukrainian].

3. Korolsky, V., Kramarenko, T., Semerikov, S. \& Shokalyuk, S. (2009). Innovatsiini informatsiinokomunikatsiini tekhnolohii navchannia matematyky [Innovative information and communication technologies for teaching mathematics]. Kireevsky Book Publishing House, 324 p. [in Ukrainian].

4. Ortinsky, V. (2019). Pedahohika vyshchoi shkoly: navch. posib [Pedagogy of higher school: textbook]. Center for Educational Literature. 472 p. [in Ukrainian].

5. Otych, O. (2010). Pedahohika mystetstva: vid istorychnoi praktyky - do teoretychnoho osmyslennia [Pedagogy of art: from historical practice to theoretical understanding]. Native school. Vol.6. pp. 14-19. [in Ukrainian].

6. Standart vyshchoi osvity Ukrainy: pershyi (bakalavrskyi) riven, haluz znan 01 - "Osvita/ Pedahohika", spetsialnist 012 - "Doshkilna osvita [Standard of higher education of Ukraine: first (bachelor's) level, field of knowledge 01 - "Education. Pedagogy", specialty 012 - "Preschool education"]. Available at: https://mon.gov.ua/storage/app/media/ vishchaosvita/zatverdzeni\%20standarty/2019/11/22/ 2019-11-22-012doshkilna-B.pdf. [in Ukrainian].

7. Chernilevsky, D. \& Tomchuk, M. (2006). Pedahohika ta psykholohiia vyshchoi shkoly [Pedagogy and psychology of higher education]. Wynn. social and economic etc.-here University "Ukraine". 402 p. [in Ukrainian].

8. Shevchuk, P. \& Fenrich, P. (2005). Interaktyvni metody navchannia: navch. posibnyk [Interactive teaching methods: textbook. manual]. Szczecin, 170 p. [in Ukrainian].

9. Effects of a play program on creative thinking of preschool children Garaigordobil, M., Berrueco, L. (2011). The Spanish Journal of Psychology Copyright 2011 by The Spanish Journal of Psychology, Vol.14. 2, pp 608-618. [in English].

Стаття надійшла до редакції 23.03.2021

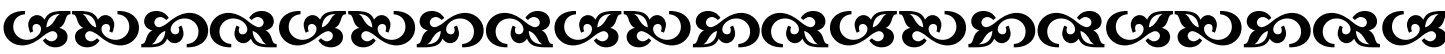

"Найвище завдання будь-яқої творчості - знайти незвичайне в звичайному $i$ звичайне у фантастичному”.

Deні Didpo

французький ббілособб

“ТТорием може бути кожен, яқщо у нього є те, що його надихає”.

Tлгатон

давньогрецький мислитель, засновникфілособської школи відомої якАкадемія Тілатона

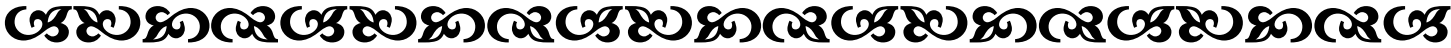

Молодь і ринок №4 (190), 2021 